\title{
Uwagi o manipulowaniu znaczeniami słów
}

\author{
Beata POLANOWSKA-SYGULSKA*
}

\begin{abstract}
On manipulating the meaning of words: The strategy of distorting the meaning of concepts in order to redirect people's attitudes has been put in practice by ideologists and politicians for years. The paper focuses on the reflections of selected thinkers and men of letters on this phenomenon. Intellectual contributions of Isaiah Berlin, Friedrich A. Hayek, Leszek Kołakowski and Charles L. Stevenson on the one hand, and the considerations of George Orwell, Aldous Huxley, Ayn Rand, Sławomir Mrożek and Małgorzata Musierowicz on the other hand are analysed. Some recent incarnations of the tactics of perverting the meaning of words in recent political discourse in Poland are critically examined. Special attention is given to the manipulating the meaning of "paedophilia" in the context of the nationwide discussion on child sexual abuse in the Catholic Church. It is concluded that the dishonourable practice of verbal misrepresentation used under Communism is at work again, this time in even more sophisticated form.
\end{abstract}

\section{KEYWORDS}

Isaiah Berlin; Friedrich A. Hayek; Leszek Kołakowski; Charles L. Stevenson; distorted notions; persuasive definitions; toleration; freedom

* Prof. dr hab., Katedra Teorii Prawa, Wydział Prawa i Administracji, Uniwersytet Jagielloński w Krakowie. E-mail: beata.polanowska-sygulska@uj.edu.pl. 


\section{ISAIAH BERLIN I APEL O OCHRONĘ WOLNOŚCI JEDNOSTKI}

Dwie koncepcje wolności Isaiaha Berlina czytałam po raz pierwszy w czasie nocy stanu wojennego. Lektura pierwszych stron była jak uderzenie obuchem. Przeniosła mnie ona ze świata beznadziei i przemocy na spotkanie z mędrcem, który rozumie absolutnie wszystko - i uwłaczające ludzkiej godności realia, i nieunikniony w tej sytuacji gniew. Nie tylko rozumie; on to zgłębit, przemyślał i nazwał. Przedstawił jak na dłoni owo niesłychane nadużycie intelektualne, jakim jest argumentacja za stosowaniem przymusu $\mathrm{w}$ imię wcielenia $\mathrm{w}$ życie ni mniej, ni więcej tylko ideału wolności. Wyjaśnił strategię manipulowania znaczeniami stów i jej niszczycielskie następstwa. Jego mistrzowska analiza metafizyki racjonalistycznej rzuciła mocne światło na naturę paternalistycznego modelu traktowania poddanych. Jakąż ulgę niosła ze sobą lektura następującego fragmentu rozważań filozofa:

Wydaję rozkazy, a jeśli stawiasz opór, biorę na siebie zadanie stłumienia tego nieracjonalnego elementu, który w tobie przeciwstawia się rozumowi. [...] Jeśli zabrakło ci samodyscypliny, ja muszę cię wyręczyć; i nie możesz skarżyć się na brak wolności, ponieważ fakt, że rozumny sędzia Kanta posłał cię do więzienia, dowodzi, że nie słuchałeś swojego własnego, wewnętrznego rozumu, że jak dziecko, dzikus, idiota nie dojrzałeś do kierowania sobą lub jesteś trwale do tego niezdolny (Berlin, 1994a: 214).

O ile łatwiej było się rozeznać we własnych splątanych, negatywnych emocjach, po przeczytaniu poniższego akapitu:

wszystkie paternalistyczne rządy, jakkolwiek dobroczynne, ostrożne, bezstronne, racjonalne w końcu skłaniały się ku traktowaniu większości ludzi jako niepełnoletnich lub nazbyt często nieuleczalnie głupich czy nieodpowiedzialnych albo też dojrzewających tak wolno, że nie dawało to podstaw do ich wyzwolenia w jakimś dającym się jasno określić momencie (co w praktyce oznaczało - nigdy). Taka strategia polityczna degraduje ludzi i [...] opiera się [...] na całkowicie fałszywej wizji najgłębszych potrzeb ludzkich (Berlin, 1994b: 58).

Moją szczególną uwagę przykuły przemyślenia Berlina na temat podejmowanych przez autorytarną władzę zabiegów prowadzących do zmiany znaczeń słów. Płomienny apel filozofa o ochronę wolności negatywnej, rozumianej jako respektowanie przynależnej każdej jednostce sfery nieingerencji, jest ostrzeżeniem przed niebezpieczeństwem, jakie niesie z sobą przyjęcie pozytywnej interpretacji tego pojęcia, utożsamiającej wolność z samokontrolą. W największym skrócie główna teza eseju Berlina przedstawia się następująco ${ }^{1}$. W'sród ponad

${ }^{1}$ O koncepcji wolności Berlina pisałam już wielokrotnie, przede wszystkim w: Polanowska-Sygulska, 1998, i w pomniejszych publikacjach, ale nakreślę ją tutaj w najogólniejszych zarysach jeszcze raz. 
dwustu znaczeń słowa „wolność” można wyodrębnić dwa, które w największym stopniu wpłynęły na dzieje ludzkości: „wolność od”, czyli wolność negatywną, oraz „wolność do”, określaną również mianem wolności pozytywnej. Zdaniem filozofa to pierwsze rozumienie wyraża podstawowy sens wolności — „od kajdan, więzienia, zniewolenia przez innych” (Berlin, 1994b: 52). To drugie odzwierciedla w pełni uzasadnione człowiecze dążenie do kierowania własnym życiem. Oba rozumienia są na równi uprawnione, bowiem każde z nich jest wyrazem głębokiej ludzkiej potrzeby. Nie są od siebie zbyt odległe; ich zakresy do pewnego stopnia na siebie zachodzą. Niemniej ich rozbieżna ewolucja sprawiła, że w okresie zimnej wojny doszło do bezpośredniego konfliktu między nadbudowanymi nad nimi koncepcjami. Filozof zdecydowanie podkreśla, że oba ujęcia wolności były w ciągu dziejów nadużywane i że oba mają na swym koncie bezmiar zła i ludzkich cierpień. Niemniej tylko jedno z nich charakteryzuje się szczególną podatnością na wypaczenia. Pozytywne rozumienie wolności, kładące nacisk na samodoskonalenie i samokontrolę, zakłada hierarchiczną strukturę osobowości. Jeśli wolność zasadza się na byciu własnym panem, to oznacza, że w człowieku jest zarówno ten, który kontroluje, jak i ten, którego niedojrzałość, ignorancja, namiętności i żądza natychmiastowych przyjemności wymagają kontroli. Innymi słowy, pozytywne rozumienie wolności łączy się z psychologiczną koncepcją dwóch jaźni — „wyższej”, „autentycznej” i „niższej”, „empirycznej”. Niebezpieczeństwo pojawia się w momencie rozszerzenia owej „wyższej” jaźni na pewną całość społeczną, do której jednostka należy — na plemię, Kościół, państwo, rasę, wielką społeczność żyjących, zmarłych i jeszcze nienarodzonych. Oczywistą konsekwencją takiego utożsamienia jest uznanie, że owa kolektywnie rozumiana „wyższa” jaźń jest w pełni uprawniona do stosowania nie tylko kontroli, lecz także przymusu względem jednostek w imię ich własnej wolności. Za sprawą takiego oto zabiegu teoretycznego sięgający swymi korzeniami starożytności szlachetny ideał indywidualnego samodoskonalenia przerodził się w doktrynę autorytarnego państwa. Berlin identyfikuje opisany powyżej mechanizm nade wszystko w tradycji oświeconego racjonalizmu, począwszy od Barucha Spinozy aż po późnych uczniów Georga Hegla. Omówiona powyżej linia argumentacyjna znalazła swoje najwyrazistsze ucieleśnienie w filozofii Johanna G. Fichtego. Na potwierdzenie powyższej tezy autor Dwóch pojęć wolności przytacza następujący fragment z pism niemieckiego filozofa:

Mędrzec zna cię lepiej, niż ty sam znasz siebie, bo jesteś ofiarą własnych namiętności, niewolnikiem uległym władzy pobudek, tępakiem niezdolnym do zrozumienia swoich prawdziwych celów. Chcesz być człowiekiem. Zadaniem państwa jest zaspokojenie tego pragnienia (cyt. za: Berlin, 1994a: 210).

Nie sposób w tym miejscu przybliżyć wszystkich doniosłych wątków wywodu Berlina, jak choćby dokonanej przezeń mistrzowskiej rekonstrukcji czterech 
założeń, wpisanych w racjonalistyczną metafizykę (Berlin, 1994a: 215). Poruszę jeszcze jedną kwestię, która bezpośrednio wiąże się z praktyką wypaczania znaczeń stów.

Obok przestrogi przed fatalnym w skutkach przejściem od interpretacji jednostkowej do społecznej, jakie dokonało się w ramach tradycji hołdującej pozytywnemu rozumieniu wolności, filozof formułuje kolejne ostrzeżenie. Tym razem odnosi się ono nie do „kuglarskiej sztuczki”, w wyniku której wolność zostaje zrównana z niewolą, lecz do praktyki nadmiernego rozciągania zakresu terminów. Wspomniany zabieg sprawia, że stają się one tak rozmyte, iż w efekcie tracą jakiekolwiek znaczenie. Wedle Berlina czym innym jest wolność jako taka, a czym innym warunki jej urzeczywistnienia. Rozszerzanie zakresu pojęcia „wolność", w wyniku czego środki umożliwiające czynienie z niej użytku zostają włączone do denotacji wchodzącej w grę nazwy, prowadzi do pomieszania pojęć. Filozof obstaje przy jasności wypowiedzi i precyzji w używaniu języka, formułując następujące spostrzeżenie: „Wszystko jest tym, czym jest: wolność jest wolnością, a nie równością, uczciwością, sprawiedliwością, kulturą, szczęściem człowieczym, albo spokojnym sumieniem” (Berlin, 1994a: 186). Nic bowiem nie zyskujemy na pomieszaniu pojęć. Zaciemnia ono obraz rzeczywistości i może się okazać destrukcyjne w skutkach. Filozof przyznaje, że brak środków umożliwiających danemu podmiotowi korzystanie z przyznanej mu sfery wolności sprawia, że staje się ona dla niego faktycznie bezużyteczna, niemniej jej nie unicestwia. Natomiast odwrotna sytuacja może się okazać zgubna. Sięgnijmy wprost do wywodu oksfordzkiego myśliciela:

Dążąc gorliwie do stworzenia społecznych i ekonomicznych warunków, w których jedynie wolność jest autentyczną wartością, ludzie zapominają często o samej wolności, a gdy pamiętają, łatwo usuwają ją w cień, by urzeczywistnić inne wartości, absorbujące przede wszystkim umysły reformatorów i rewolucjonistów (Berlin, 1994b: 50).

Ta druga przestroga jest kolejnym mocnym przesłaniem, płynącym z Dwóch pojęć wolności.

Pochłaniałam te słowa jak w upojeniu. Rozpoznawałam w nich strzępy własnych myśli. Jest ktoś, kto „wziął pod lupę” źródło dotkliwie odczuwanego przeze mnie upokorzenia i gniewu, rozszyfrował je i rozłożył na czynniki pierwsze. Sytuacja pozostała ta sama, ale świat się zmienił. Znienawidzone frazy: „praworządność socjalistyczna” (w rzeczywistości system gwarantowanego prawem bezprawia) czy „demokracja socjalistyczna” (de facto dyktatura partii komunistycznej) stały się przedmiotem analizy i refleksji, dzięki czemu ich odstręczająca moc uległa znacznej redukcji. Po pierwszym olśnieniu przyszło drugie. Nawiązałam listowny kontakt z Berlinem i zostałam przez niego zaproszona do Oksfordu. Po pierwszym pobycie przyszły następne. Dojmujące poczucie wolności, jakie zostało mi podarowane, sprawiło, że groza, jaką niegdyś niosły 
ze sobą nieznośne językowe „przekręty”, gdzieś się ulotniła. Pamiętam jedno z naszych spotkań, w trakcie którego zaśmiewaliśmy się, wyliczając uprawnienia obywateli państw komunistycznych. Sir Isaiah sypał jak z rękawa stosownymi przykładami:

Masz uprawnienie do ubiegania się o członkostwo w partii. [...] Masz uprawnienie do zadenuncjowania drugiego za jego kontrrewolucyjną postawę. Jakie masz jeszcze inne uprawnienia? Masz uprawnienie do bycia wdzięcznym, masz uprawnienie do wysławiania przywódcy. [...] Masz uprawnienie do podniesienia wydajności w fabryce poprzez wydłużenie godzin pracy. Masz uprawnienie do zostania stachanowcem (Polanowska-Sygulska, 2011: 36-37).

W czasie mojej pierwszej wizyty w Oksfordzie, która przypadła w roku 1986, Berlin wspomniał o spotkaniu z polskim filozofem, które właśnie odbył. Oczywiście znałam nazwisko Ryszarda Legutki. Kilka dni później miałam okazję poznać go osobiście na zebraniu polskich stypendystów. Krakowski filozof był pod wielkim wrażeniem rozmowy z Berlinem. Po latach nie jestem już w stanie dosłownie odtworzyć tego, co mi wówczas powiedział. Pamiętam jednak doskonale treść jego komentarza i jedno charakterystyczne słowo, które padło. Legutko był zachwycony właściwym Berlinowi sposobem formułowania myśli, dzięki któremu, jak się wyraził, wypowiedzi filozofa tak pięknie komponują się w spójną strukturę. Wieńcząca ją teza stanowi klamrę, spinającą w całość przeprowadzony wywód. Utkwiło mi pamięci mocno wyakcentowane słowo "pięknie".

Nic nie wskazywało na radykalną zmianę tonu wypowiedzi krakowskiego filozofa, która miała z czasem nadejść.

\section{CREDO „WOLNOŚĆ TO NIEWOLA” W LITERATURZE PIĘKNEJ²}

Przywilej osobistych kontaktów z oksfordzkim myślicielem i lektura jego prac - obok ogromnego wpływu, jaki wywarły na moje życie - wyczuliły mnie na zjawisko wypaczania pojęć. Sam fenomen ma długotrwałą tradycję i przykuł uwagę wielu autorów, w tym także literatów.

Pierwszym, niejako automatycznym skojarzeniem jest Orwellowska dystopia Rok 1984 wraz z rozwiniętą w niej ideą nowomowy, której „nadrzędnym celem jest zawężenie zakresu myślenia” (Orwell, 1988: 10). Charakterystykę nowomowy George Orwell wkłada w usta jednego z bohaterów, który jest ekspertem pracującym nad redakcją kolejnego wydania słownika zreformowanego języka:

${ }^{2}$ Do przemyśleń na temat wypaczania pojęcia wolności „wolności” zawartych w wybranych dziełach literackich i filozoficznych nawiązałam już, jakkolwiek w znacznie węższym zakresie, w: Polanowska-Sygulska, 2012: 43-48. 
Nadajemy językowi ostateczny kształt: taki, jaki będzie miał, gdy wszyscy zaczną się wyłącznie posługiwać nowomową. [...] Niszczenie stów to coś pięknego. Najwięcej, oczywiście, wyrzucamy czasowników i przymiotników, ale setki rzeczowników też są zupełnie zbędne. Usuwamy nie tylko synonimy, ale także wyrazy przeciwstawne. Bo jaką rację bytu mają słowa, których znaczenie jest po prostu przeciwieństwem innych? Każde słowo zawiera w sobie swoje przeciwieństwo. Weźmy na przykład przymiotnik „dobry”. Jeśli mamy „dobry”, po co nam taki przymiotnik jak „zły”? „Bezdobry” wystarczy w zupełności [...]. A gdy z kolei chcemy coś wzmocnić, czy ma sens stosowanie mętnych i w sumie bezużytecznych określeń typu „wspaniały” lub „znakomity”? „Plusdobry" adekwatnie spełnia każdy wymóg, jeśli natomiast zachodzi potrzeba jeszcze większej emfazy, można użyć „dwaplusdobry” (Orwell, 1988: 10).

Ducha Orwellowskiej wizji totalitaryzmu znakomicie wyrażają nazwy czterech ministerstw, współtworzących aparat rządowy: Ministerstwo Prawdy (czyli: propagandy), któremu podlegały prasa, rozrywka, oświata i sztuka, Ministerstwo Pokoju, które zajmowało się prowadzeniem wojny, Ministerstwo Miłości (czyli: bezpieczeństwa wewnętrznego) oraz Ministerstwo Obfitości (czyli gospodarki). Znaczące są też trzy hasła Partii, wymalowane na fasadzie Ministerstwa Prawdy i cykliczne wyświetlane na teleekranach, zamontowanych we wszystkich pomieszczeniach:

WOJNA TO POKÓJ

WOLNOŚĆ TO NIEWOLA

IGNORANCJA TO SIŁA (Orwell, 1988: 7, 15, 22).

Inny kojarzony z dystopią autor - Aldous Huxley - podejmuje temat manipulowania znaczeniami słów w książce Niewidomy $w$ Ghazie. Pojęciem, nad treścią którego dyskutują dwaj bohaterowie tej na wpół autobiograficznej powieści, jest „wolność. Warto zauważyć, że wspomniana książka ukazała się po raz pierwszy w 1936 roku, to jest blisko dwie dekady wcześniej niż esej Berlina. Przytoczmy wymianę argumentów, jakie padły w zamieszczonej w powieści rozmowie:

- Ale kto chce zdobyć wolność musi stać się niewolnikiem. Jest to warunek zdobycia wolności - prawdziwej wolności.

— Prawdziwa wolność! — powtórzył Antoni, parodiując głos księdza. — Przeciwieństwo czegoś nie jest przeciwieństwem. O mój Boże, skądże znowu! Jest właśnie tą samą rzeczą, tylko prawdziwą. Zapytaj skrajnego konserwatysty, czym jest konserwatyzm, a odpowie ci, że to prawdziwy socjalizm. A w zawodowych pismach gorzelniczych pełno jest artykułów o pięknie prawdziwej wstrzemięźliwości. Zwyczajna wstrzemięźliwość jest po prostu ordynarnym powstrzymywaniem się od pijaństwa, ale prawdziwa wstrzemięźliwość to coś znacznie wykwintniejszego. Prawdziwa wstrzemięźliwość to butelka wina przy każdym positku i trzy duże kieliszki whisky po obiedzie. Co do mnie, jestem zwolennikiem prawdziwej wstrzemięźliwości, ponieważ wstrzemięźliwości nie cierpię. Ale cenię wolność i dlatego nie chcę mieć nic do czynienia z prawdziwą wolnością. 
- Co nie przeszkadza, że prawdziwa wolność istnieje — nalegał Brian z uporem.

- Czym jest nazwa? - ciągnął dalej Antoni. - Należy odpowiedzieć, że jest właściwie wszystkim, jeśli dobrze brzmi. Wolność to wspaniała rzecz i dlatego człowiek pragnie gorąco używać wolności. Zdaje ci się, że jeżeli ochrzcisz niewolę mianem prawdziwej wolności, przyciągniesz tym ludzi do więzienia. A co gorsza masz zupełną słuszność (Huxley, 1957: 112-113).

Świadectwem szczególnej wagi są przemyślenia literatów, którzy mieli osobiste doświadczenie życia $\mathrm{w}$ systemie komunistycznym. Przenikliwą analizę słownej żonglerki, w wyniku której różnica między wolnością i niewolą zostaje całkowicie zniwelowana, przedstawiła w swojej powieści Zródto Ayn Rand, amerykańska pisarka i myślicielka, twórczyni systemu filozoficznego, któremu nadała miano obiektywizmu. Urodzona z początkiem XX wieku w Rosji była świadkiem rewolucji bolszewickiej. W 1925 roku uzyskała pozwolenie na krótkotrwały wyjazd do USA, który zapoczątkował jej dożywotnią emigrację. We wspomnianej, opublikowanej w 1943 roku powieści zamieściła następujący monolog jej negatywnego bohatera:

Największym problemem nowoczesnego świata [...] jest błędne przekonanie, że wolność i przymus są sprzeczne. Aby rozwiązać ów gigantyczny problem, który miażdży dzisiejszy świat, musimy opanować nasz chaos umysłowy. Musimy uzyskać perspektywę filozoficzną. Wolność i przemoc są w gruncie rzeczy tym samym. Pozwolę sobie podać prosty przykład. Światła uliczne ograniczają waszą wolność przechodzenia przez ulicę, kiedykolwiek mielibyście na to ochotę. To ograniczenie uwalnia was jednak od niebezpieczeństwa zostania przejechanymi przez ciężarówkę. Jeżeli przypisano by was do jakiejś pracy i nie pozwolono z niej odejść, ograniczałoby to waszą wolność wyboru. Uwolnitoby was jednak od strachu przed bezrobociem. Kiedykolwiek nakłada się na nas nowy przymus, automatycznie zyskujemy nową wolność. Te dwie rzeczy są nierozdzielne. Tylko przez akceptację totalnego przymusu możemy uzyskać totalną wolność (Rand, 2007: 641).

Powyższy wywód nieodparcie przywodzi na myśl słynną Engelsowską parafrazę tezy wywodzącej się z filozofii Hegla: „wolność to uświadomiona konieczność”. Paradoks zrównania wolności z jej radykalnym zaprzeczeniem znalazł także oddźwięk w twórczości polskiego dramaturga - Sławomira Mrożka który, podobnie jak Rand, przeżył lata młodości pod rządami dyktatury komunistycznej. Mrożek zmierzył się z tematem wypaczania pojęć w jednoaktówce Na petnym morzu (Mrożek, 1961). W charakterystycznym dla siebie, absurdalno-sarkastycznym stylu nakreślił specyficzny kontekst sytuacyjny, w jakim przyszło jednemu z bohaterów wygłosić znamienną mowę o wolności. Oto dryfujący na tratwie trzej zagrożeni głodem rozbitkowie — Gruby, Średni i Mały — rozważają racje przemawiające za pozbawieniem życia jednego z nich w imię przetrwania dwóch pozostałych. Mistrzowsko zrelacjonowana debata prowadzi do podjęcia nieodwołalnej decyzji, zgodnie z którą Mały ma zostać 
skonsumowany przez swoich towarzyszy. W obliczu nieuchronności nadchodzących wydarzeń przyszła ofiara przechodzi metamorfozę, w wyniku której wzbudza w sobie stan pełnej akceptacji sytuacji, w jakiej się znajduje, osiągając tym samym „prawdziwą” wolność:

Ostatecznie to zupełnie co innego zostać zjedzonym jako zwyczajna ofiara przemocy, a co innego jako inny, lepszy człowiek, który z własnego poświęcenia... Innymi słowy, być zjedzonym za własnym wewnętrznym przyzwoleniem, razem ze szlachetnymi pobudkami. [...] Panowie, dziękuję wam. Nareszcie stałem się pełnym człowiekiem. Odnalazłem w sobie ideały, których mi było brak (Mrożek, 1961: 137-138).

Zwieńczeniem tej gorzkiej, szyderczej groteski jest wyżej wspomniana mowa o wolności, wygłoszona przez Małego:

Wolność to nic nie znaczy. Dopiero prawdziwa wolność to znaczy coś. Dlaczego? Bo jest prawdziwa, a więc lepsza. Wobec tego gdzie szukać prawdziwej wolności? Pomyślmy logicznie. Jeżeli prawdziwa wolność to nie jest to samo, co zwykła wolność, to wobec tego gdzie jest prawdziwa wolność. To jasne. Prawdziwa wolność jest tylko tam, gdzie nie ma zwyczajnej wolności (Mrożek, 1961: 139).

W finale okazuje się, że ofiara Małego jest niepotrzebna, niemniej Gruby przeciwstawia się jej poniechaniu. Wskazując na Małego, zwraca się do Średniego w te słowa: „Czy Pan nie widzi, że on już jest szczęśliwy?” (Mrożek, 1961: 139).

Trudno się dziwić, że ktoś obdarzony taką wrażliwością i wyczuleniem na przejawy absurdu, a zarazem tak ogromną wnikliwością nie był w stanie funkcjonować w ówczesnej polskiej rzeczywistości. Notabene powrót do ojczyzny po upadku komunizmu po kilkunastu latach zaowocował ponowną emigracją. Pisarz zmarł na obczyźnie.

$\mathrm{Na}$ najnowsze - wydawałoby się zaskakujące - literackie nawiązanie do praktyki przeinaczania znaczeń słów natknęłam się w książce znanej autorki książek dla młodzieży Małgorzaty Musierowicz (siostry Stanisława Barańczaka). Jej z pozoru popularne powieści zawierają niemało głębokich uwag. Dość powiedzieć, że wiernym czytelnikiem wielotomowej Jeżycjady był Czesław Miłosz, który pozostawał w kontakcie z autorką. W 21 tomie zatytułowanym $\mathrm{Fe}^{-}$ blik, jeden z bohaterów, który jest językowym purystą, wypowiada następującą kwestię:

To ważne, co się mówi. I pisze. Słów trzeba używać precyzyjnie, w ich właściwym znaczeniu - inaczej fałszują rzeczywistość. A zafałszowana rzeczywistość wytwarza nowe fałszywe słowa. Tworzy się wielki obieg fałszu, który rodzi ogromne kłamstwo. A kłamstwo rodzi zło (Musierowicz, 2015: 214).

Warto zwrócić uwagę na znamienną datę ukazania się Feblika — listopad 2015. 


\section{ŻONGLERKA ZNACZENIAMI WYRAŻEŃ W REFLEKSJI FILOZOFICZNEJ}

Sięgnijmy do wybranych przemyśleń na temat językowych manipulacji, dokonywanych już nie w tekstach literackich, lecz w rozważaniach o stricte intelektualnym charakterze. Wśród wielkich dwudziestowiecznych liberałów powyższy temat, obok Berlina, podjął także Friedrich von Hayek. Notabene pierwszy zapis jego dociekań, poświęconych taktyce wykoślawiania znaczeń słów poprzedza ukazanie się Berlinowskich Dwóch pojęć wolności. Znajdujemy go w wojennym traktacie Hayeka Droga do zniewolenia, opublikowanym w 1944 roku. Ten żarliwy manifest na rzecz ochrony wolności indywidualnej był zarazem ostrzeżeniem przed niebezpieczeństwem, jakie stanowi dla niej socjalizm:

By uspokoić podejrzenia i zaprząc do swego wozu najsilniejszy z wszystkich politycznych motywów - pragnienie wolności, socjalizm począł czynić coraz większy użytek z obietnicy „nowej wolności”. Nadejście socjalizmu miało być skokiem z królestwa konieczności w królestwo wolności. Miał on przynieść „wolność ekonomiczną”, bez której osiągnięta już „wolność polityczna” nie warta była zachowania. Tylko socjalizm miał być zdolny do uwieńczenia sukcesem odwiecznej walki o wolność, w której osiągnięcie wolności politycznej było jedynie pierwszym krokiem (Hayek, 2003: 37).

Hayek rozwija powyższą myśl, eksponując wątek manipulacji słowem „wolność":

Istotna jest tu subtelna zmiana znaczenia, jakiej poddano słowo „wolność”, aby argument brzmiał przekonywająco. Dla wielkich apostołów wolności politycznej słowo to oznaczało wolność od przymusu, wolność od arbitralnej władzy innych ludzi, uwolnienie od więzi niepozostawiających jednostce innego wyboru, prócz posłuszeństwa wobec poleceń zajmującej wyższą pozycję osoby, której jednostka została przypisana. Nowa zaś, obiecywana wolność miała być wolnością od konieczności, uwolnieniem od przymusu warunków, które w sposób nieuchronny wszystkim nam ograniczają zakres wyboru, choć niektórym znacznie bardziej niż innym. Zanim człowiek naprawdę stanie się wolny, musi zostać przełamana "tyrania potrzeb materialnych" i muszą być rozluźnione „ograniczenia systemu gospodarczego" (Hayek, 2003: 37-38).

Myśliciel zauważa, że dokonana przez socjalistów modyfikacja sprawiła, iż słowo „wolność" utraciło swe dotychczasowe znaczenie i w istocie rzeczy stało się synonimem mocy (power) bądź bogactwa. Stary postulat zrównania statusu ekonomicznego przeobraził się w żądanie przyznania ludziom tak rozumianej

${ }^{3}$ Cytuję, wprowadzając pewną modyfikację do polskiego tłumaczenia. Użyta w oryginale fraza: economic freedom została przełożona jako „wolność gospodarcza”, co w przytoczonym kontekście nie jest adekwatne, a może także być mylące. Nie chodzi bowiem o wolność podejmowania działalności gospodarczej, lecz o warunki realizacji wolności indywidualnej, która przysługuje jednostce. 
wolności. Zdaniem Hayeka powyższe zafałszowanie umknęło uwadze tych, którzy dali się zmanipulować:

nowemu ujęciu nadali socjaliści inną, wspólną z liberałami nazwę, i w pełni ją wykorzystali. Mimo iż samo słowo używane było przez obie grupy w odmiennym sensie, mało kto zwrócił na to uwagę, a jeszcze mniej ludzi zadawało sobie pytanie, czy te dwa rodzaje obiecywanej wolności dadzą się rzeczywiście ze sobą połączyć (Hayek, 2003: 38).

Powyższy wywód prowadzi austriackiego noblistę do sformułowania pesymistycznej prognozy: „to, co nam obiecano jako Drogę do Wolności, jest w rzeczywistości najprostszą Drogą do Niewoli” (Hayek, 2003: 38). Po latach ten sam wątek zostaje rozwinięty w kluczowym dziele Hayeka z 1960 roku Konstytucji wolności. Po raz kolejny myśliciel ostrzega przed werbalną sztuczką socjalistów, z której następnie poczyniono pełny użytek w krajach o totalitarnym systemie rządów:

Żaden z przypadków mieszania wolności jednostki z różnymi pojęciami oznaczanymi tym samym słowem nie jest tak niebezpieczny, jak mylenie jej [...] z użyciem słowa „wolność” na określenie fizycznej możliwości „robienia, co chcę”, zdolności zaspokajania naszych pragnień, czyli zakresu wyboru otwartych przed nami alternatyw. [...] do względnie niedawna tylko nieliczni ludzie serio mylili tę „wolność od” przeszkód, która równałaby się wszechmocy, z wolnością indywidualną, którą mógłby zapewnić dowolny ustrój społeczny (Hayek, 2007: 30).

W Konstytucji wolności Hayek ponownie obwinia socjalistów za to językowe szalbierstwo. Dokonana przez nich manipulacja pojęciem wolności zdaniem myśliciela niesie z sobą niefortunne następstwa:

Pomieszanie to stało się jednak niebezpieczne dopiero z chwilą, gdy zostało świadomie przyjęte jako część tezy socjalistycznej. Jeśli bowiem zaakceptuje się to utożsamienie wolności z możnością, przestają istnieć granice dla sofizmatów służących wykorzystaniu słowa „wolność" do uzasadnienia środków, które niszczą wolność jednostki, nie ma kresu dla sztuczek, za pomocą których ludzie mogą być nakłaniani w imię wolności do wyrzeczenia się wolności. To z pomocą tej dwuznaczności pojęcie wolności jednostki zostało zastąpione przez pojęcie kolektywnego panowania nad warunkami, a wolność w państwach totalitarnych stłumiono w imię wolności (Hayek, 2007: 30).

Warto zauważyć, że diagnozy Berlina i Hayeka są w generalnym planie do siebie zbliżone. Abstrahując od możliwych do zidentyfikowania różnic obaj myśliciele, opowiadając się za negatywnym ujęciem wolności, z którym wiążą istnienie respektowanej sfery niezależności jednostki, ostrzegają przed zgubnymi konsekwencjami przyjęcia alternatywnej interpretacji tegoż ideału. Wedle Berlina owym niosącym ze sobą zagrożenie rozumieniem wolności jest pozytywne odczytanie tego pojęcia, utożsamiające wolność z kontrolą. Zdaniem 
Hayeka destruktywnym w skutkach ujęciem wolności jest zrównanie jej z mocą (power). Mimo powyższej różnicy w zlokalizowaniu źródła niebezpieczeństw dla wolności indywidualnej obaj myśliciele upatrują największą groźbę w rozciągnięciu zidentyfikowanego przez siebie rozumienia wolności na pewną całość społeczną. U Berlina jest to transformacja pojęcia „wyższej jaźni”, w wyniku której dochodzi do utożsamienia tejże jaźni z jakąś ponadjednostkową strukturą; u Hayeka zaś odniesienie wolności pojętej jako moc do kolektywu. W obu przypadkach konsekwencją zastąpienia liberalnego ujęcia wolności jej nowym, rozszerzonym na całość społeczną odczytaniem jest stosowanie ucisku w imię wolności. Co więcej, obaj myśliciele piętnują jeszcze inną, niebezpieczną tendencję, jaką jest nadmierne rozciąganie pojęcia „wolność” na rozmaite, pozytywnie oceniane stany społeczne. Podobnie jak Berlin, Hayek utrzymuje, że „wolność nie oznacza wyłącznie rzeczy dobrych czy braku wszelkiego zła” (Hayek, 2007: 31).

Przejdźmy teraz do rozważań nad wolnością autorstwa filozofa, który $\mathrm{w}$ przeciwieństwie do powyższych nie identyfikował się z liberalizmem, stronił bowiem od jakichkolwiek etykietek. Bliska mu była jednak idea wolności negatywnej, zaś rozumienie wolności, które odnosi ją nie do jednostek, lecz do całości społecznej, uważał za zagrożenie. Mam tu na myśli jednego z najwybitniejszych krytyków marksizmu, Leszka Kołakowskiego. Warto sięgnąć do jego esencjonalnego artykułu Wolność i wolności z 1972 roku, włączonego do tomu Czy diabet może być zbawiony i 27 innych kazań. Filozof stawia tam pod znakiem zapytania prawomocność odnoszenia idei wolności do kolektywu:

Czym [...] jest „wolność” całości kompletnie wyobcowana w stosunku do wolności jednostek składających się na tę całość? Dlaczego mielibyśmy w ogóle określać ją jako „wolność" i dlaczego uważać ją za godną pożądania? Definicja Engelsa [wolność to „zrozumienie konieczności” - przyp. B.P.S.] jest tylko jednym z wielu przykładów aberracji, do jakiej można dojść, kiedy pojęcia odnoszące się do „dobra ogólnego” usiłuje się całkowicie uniezależnić od dobra poszczególnych ludzi. Gdy już uda się taka operacja myślowa, nie ma tak monstrualnego systemu społecznego, który nie dałby się sławić jako wcielenie najwyższej wolności (Kołakowski, 2006: 337).

W dalszym ciągu dociekań Kołakowski ostrzega — podobnie jak Berlin i Hayek - przed nadmiernym rozciąganiem zakresu pojęcia „wolności”:

Sama sytuacja technologiczna naszego świata sprawia, że coraz więcej ważnych decyzji społecznych musi być podejmowanych przez centralne ośrodki władzy i grona ekspertów i że poczucie bezsilności jednostki w stosunku do organizmu społecznego jako całości może wzrastać. Najgorszą rzeczą, jaką w obliczu tej perspektywy możemy uczynić, jest obciążenie pojęcia „wolności” coraz nowymi i coraz liczniejszymi zadaniami, wśród których pierwotny i zwyczajny sens tego pojęcia ginie w końcu jako nieważny szczegół (Kołakowski, 2006: 338). 
Wreszcie, tak samo jak Berlin i Hayek, polski filozof eksponuje dwie interpretacje pojęcia „wolności”, z których jedną uważa za uprawnioną, drugą zaś identyfikuje jako słowną manipulację. Kołakowski ostrzega przed forsowaniem alternatywnej — w stosunku do tradycyjnej, liberalnej — interpretacji pojęcia wolności, wskazując, że zagraża ona niezależności jednostki. Główna różnica między przestrogami, sformułowanymi przez trzech przywołanych filozofów zasadza się na odmiennej terminologii. Berlinowska „wolność pozytywna” i Hayekowska wolność pojęta jako „moc” (power) u Kołakowskiego przyjmuje postać wolności materialnej:

Jeśli wyrażenie „wolność formalna” znaczy tyle co zakres decyzji, jaki organizacja społeczna i prawo pozostawiają do uznania jednostki, to „wolność formalna” nie oznacza nic innego jak wolność po prostu i żadnej innej wolności niż „formalna” nie ma. Jeśli jednak ktoś używa wyrażenia „wolność formalna” w taki sposób, iż daje do zrozumienia, że ma w pogotowiu inną, lepszą, „nieformalną” wolność, którą można by lub należałoby ową ,formalną" wolność zastąpić, wówczas wzywa po prostu, pod oszukańczym pretekstem słownym, do zniszczenia wolności (Kołakowski, 2006: 338-339).

Motyw zniekształcania znaczeń słów znajdujemy również w późniejszych wypowiedziach Kołakowskiego. W 2 tomie rozmowy ze Zbigniewem Mentzlem Czas ciekawy, czas niespokojny filozof relacjonuje wydarzenia, których był świadkiem w 1968 roku w USA, w czasie rewolty młodzieżowej. Ubolewa nad niedojrzałością i ignorancją protestujących studentów, ostro krytykując ich intelektualnego guru, Herberta Marcusego. W szczególności zarzuca mu językową manipulację:

W Ameryce Marcuse pisał rzeczy okropne. Weźmy choćby jego głośną rozprawę o tolerancji represyjnej. W państwach kapitalistycznych tolerancja służy dzisiaj uciskowi, co nie może być tolerowane. Istnieje nietolerancja przez przemoc i nietolerancja przez tolerancję. Ten drugi rodzaj nietolerancji jest o wiele gorszy, bo tolerancja, która rozszerza zakres i treść wolności, jest zawsze nietolerancyjna wobec przeciwników represyjnego status quo. Prawdziwa i głębsza tolerancja musi polegać na nietolerancji dla idei i ruchów, które tolerowane być nie powinny. A kto będzie miał prawo orzekać o tym, które są które? Oczywiście takie prawo będą miały siły rewolucyjne, a więc posiadacze świadomości niezmistyfikowanej przez demokratyczne środki informacji [...]. Bzdury kompletne (Kołakowski \& Mentzel, 2008: 27).

W przytoczonym fragmencie pojęciem, którego sens został wypaczony, jest nie wolność, lecz tolerancja. Niemniej zastosowana strategia jest ta sama - jej użycie doprowadziło do całkowitego zafałszowania pierwotnego znaczenia słowa. W efekcie tolerancja została utożsamiona z nietolerancją.

Ostatnia spośród przytoczonych powyżej wypowiedzi trzech myślicieli wnosi ze sobą pewien istotny element. Otóż zastosowana przez Marcusego manipulacja językowa zasadza się na opatrzeniu zafałszowanego pojęcia „tolerancja” 
przymiotnikiem: prawdziwa. Ten sam motyw pojawił się u dwóch przywołanych literatów - Huxleya i Mrożka. Ten pierwszy ironizował na temat „prawdziwego socjalizmu” i „prawdziwej wstrzemięźliwości”, ten drugi zaś wręcz szydził $\mathrm{z}$ „prawdziwej wolności”. W kontekście przytoczonych przykładów nie sposób oprzeć się skojarzeniu z przemyśleniami amerykańskiego zwolennika emotywizmu w metaetyce, Charlesa L. Stevensona.

W kilku artykułach, a także w swojej kluczowej pracy Ethics and language z 1944 roku rozwinąt on refleksję nad tak zwanymi definicjami perswazyjnymi. Wedle Stevensona nadają one znanemu słowu nową treść, nie zmieniając przy tym jego znaczenia emotywnego po to, by „dzięki interakcji między znaczeniem emotywnym i deskryptywnym przekierowywać ludzkie postawy” (Stevenson, 1944: 210). Tego rodzaju definicje można rozpoznać po występujących w nich słowach „prawdziwy” lub „rzeczywisty”. Wspomniane określniki nie są użyte dosłownie, lecz w sensie metaforycznym. Opatrzenie wyjściowego słowa przymiotnikiem „prawdziwy” sprawia, iż tak ubogacony termin nabiera mocy perswazyjnej. Ludzie bowiem uważają, że jeśli coś jest prawdziwe, to jest zarazem godne akceptacji. Sięgnijmy do wybranych przykładów, podanych przez Stevensona:

„Dobroczynność w prawdziwym sensie tego słowa nie znaczy tylko dawanie złota, ale zrozumienia. Prawdziwa miłość to jedynie komunia umystów. Rzeczywista odwaga to wewnętrzna siła, która pozwala na stawienie czoła nieprzychylnej opinii publicznej. Każde z tych stwierdzeń [...] jest środkiem, służącym przekierowywaniu postaw ludzi. Odbywa się to dzięki zachowaniu w niezmienionym kształcie emotywnego znaczenia słowa, które ma pochlebny wydźwięk, i połączenie go z nową treścią pojęciową (Stevenson, 1944: 213-214).

Wkład Stevensona jest na tyle doniosły, że wręcz nieprzyzwoitością jest poświęcenie mu zaledwie akapitu. Jednakże, z uwagi na wymogi redakcyjne, ograniczę rozmiary poczynionego nawiązania tylko do powyższej, lapidarnej dygresji.

\section{PO CO TO WSZYSTKO?}

Można postawić pytanie o sens powracania do niegdysiejszych przemyśleń na temat strategii przeinaczania znaczeń stów autorstwa myślicieli i literatów. Wszak większość z przytoczonych tekstów była inspirowana doświadczeniem totalitaryzmu — bądź osobistym, bądź przeży tym w wyobraźni. Ta epoka wszak nieodwracalnie przeminęła.

Hayek powiedział kiedyś, że ceną wolności jest ciągła czujność, nie ma bowiem żadnych gwarancji zachowania tej pierwszej. Tej czujności nam najwyraźniej

\footnotetext{
${ }^{4}$ Cytaty z prac obcojęzycznych w przekładzie autorki.
} 
zabrakło. Jesteśmy dziś świadkami powrotu dawnych, niechlubnych praktyk językowych. Ostrzeżenia liberałów i liberalnie motywowanych autorów nabrały niepokojącej aktualności, szczególnie tu i teraz. Rozważmy sposób użycia pewnych słów, które są niemal bezustannie obecne w polskim dyskursie politycznym. Sztandarowym przykładem jest „patriota”. Zgodnie z tradycyjnym znaczeniem tego pojęcia, charakteryzującego się bezdyskusyjnie pozytywnym wydźwiękiem, patriota to ktoś, komu leży na sercu dobro ojczyzny. Będzie zatem o nie zabiegat, w zależności od okoliczności historycznych. W czasach zagrożenia czy konfliktu zbrojnego będzie się angażował w działania służące zachowaniu bądź odzyskaniu niepodległości. W czasach pokoju będzie intensywnie pracował na rzecz pomyślności i zasobności swego kraju. Będzie dbał o jego wizerunek w świecie i zabiegał o jego bezpieczeństwo międzynarodowe. Będzie honorował funkcjonujący w nim porządek prawny ze szczególnym uwzględnieniem obowiązku odprowadzania podatków. Będzie wreszcie podejmował działania, służące utrzymaniu pokoju wewnętrznego i jedności społecznej, do osiągnięcia których to celów niezbędne jest otwarcie na kompromis. Gdy jednak pojawią się okoliczności wymagające jego sprzeciwu, w szczególności gdy za sprawą elit politycznych jego ojczyzna zacznie dryfować w niebezpiecznym kierunku, niezawodnie zaprotestuje. Zdecydowana krytyka, czy to na użytek wewnętrzny, czy też na forum międzynarodowym — jeśli ta ostatnia może zwiększyć szanse na zawrócenie kraju z ryzykownego kursu — będzie jego moralnym obowiązkiem. Otóż od kilku lat powszechną praktyką jest opatrywanie słowa „patriota” przymiotnikiem „prawdziwy”. Powstała fraza nadal ma pozytywny wydźwięk, lecz jej znaczenie uległo znaczącej modyfikacji. W przeciwieństwie do patrioty tradycyjnego „prawdziwy patriota” to ktoś, kto poczuwa się do obowiązku obrony ojczyzny, także - a być może przede wszystkim - w czasach pokoju, kiedy jedyni wrogowie, którzy jej zagrażają, są wyimaginowani. Nie waha się demonstrować w przestrzeni publicznej swego bojowego wzmożenia. „Prawdziwy patriota” nie dopuszcza jakichkolwiek zarzutów kierowanych pod adresem elit politycznych swojego kraju, oskarżając o zdradę tych wszystkich, którzy w imię dobra wspólnego taką krytykę podejmują. Powód do niepokoju byłby mniejszy, gdyby owym wypaczonym pojęciem szermowali wyłącznie członkowie radykalnych grup narodowych. Szafują nim jednak także niektórzy politycy i duchowni.

Mechanizm, za pomocą którego dokonuje się zniekształcenia znaczenia słowa „patriota”, w pełni wpisuje się w pochodzącą od Stevensona koncepcję definicji perswazyjnych. By dopełnić ten wątek, rozważmy jeszcze zapowiedź najważniejszego dziś polityka w państwie, która została poczyniona z początkiem sierpnia 2019 roku w Dygowie w województwie zachodniopomorskim, w trakcie pikniku rodzinnego pod hasłem „Dobry czas dla Polski”. Brzmiała ona następująco: „Pewnie nie tym razem, ale przyjdzie taki dzień, że zmienimy konstytucję na potrzebną. Konstytucję, która będzie gwarantowała prawdziwą 
demokrację, prawdziwą praworządność, prawdziwą równość, która jest dzisiaj łamana” (Rzeczpospolita, 2019). Przytoczona deklaracja jest wręcz wzorcowym przykładem wypowiedzi publicznej o charakterze perswazyjnym.

Manipulacje językowe mogą być także uskuteczniane na inne sposoby, $\mathrm{w}$ tym na takie, których ani nie opisali, ani nie przewidzieli liberalnie zorientowani autorzy. Można bowiem wypaczać znaczenie słów nie tylko przez nadmierne rozciąganie ich pierwotnej denotacji (przed czym ostrzegali Berlin i Hayek), lecz także przez ignorujące tradycję języka zacieśnianie ich zakresów. Weźmy pod rozwagę jeszcze jedną enuncjację lidera aktualnie rządzącej formacji, zgodnie z którą nasz kraj jest oazą wolności: „Polska w dzisiejszym świecie, gdzie wolność się cofa - trzeba tak to sobie jasno powiedzieć - w Europie pozostanie wyspą wolności” (Pietraszewski, 2019a). Powyższa diagnoza została postawiona z końcem marca 2019 roku, w związku z zapowiedzią odrzucenia przez polską władzę unijnej dyrektywy o prawie autorskim w Internecie, w wersji zaproponowanej przez Parlament Europejski. W kręgach populistycznej prawicy europejskiej dyrektywa audiowizualna, której celem jest ochrona interesów właścicieli praw autorskich na jednolitym rynku cyfrowym, została określona mianem „ACTA2”. W przytoczonej wypowiedzi słowo „wolność” $\mathrm{w}$ istocie rzeczy miało odniesienie wyłącznie do jednego z aspektów swobodnego funkcjonowania w Internecie. Wygłoszona w ramach kampanii wyborczej proklamacja została jednak tak sformułowana, jak gdyby w grę wchodziła wolność jako taka. Zdumiewająca to zaiste konstatacja w ustach polityka, który jest w głównej mierze odpowiedzialny za faktyczny demontaż jednej z kluczowych instytucji służących ochronie praw i wolności obywatelskich, to jest Trybunału Konstytucyjnego. Nie wspomnę już o całym pakiecie godzących w zasadę rządów prawa posunięć, które mają już swoje niechlubne przełożenie na działanie prokuratury i policji. Wystarczy tu choćby podać przykład nowelizacji Ustawy o Policji z dnia 15 stycznia 2016 roku, która między innymi umożliwia pozyskiwanie za pośrednictwem sieci teleinformatycznej danych internetowych w celu ścigania i wykrywania przestępstw. W kontekście przywołanej noweli nasuwa się następująca parafraza znanej wypowiedzi Marka Twaina: pogłoska o wolności w Internecie jest zdecydowanie przesadzona.

Przejdźmy teraz do jawnej językowej manipulacji, która była dla mnie bezpośrednim impulsem do ponownego poddania pod rozwagę taktyki wypaczania znaczeń słów. Autorem rzeczonej wypowiedzi jest przywołany na początku tego tekstu Ryszard Legutko, od 2009 roku poseł do Parlamentu Europejskiego z ramienia Prawa i Sprawiedliwości. Zanim jednak przejdę do analizy jej treści, przybliżę w kilku słowach ewolucję postawy intelektualnej profesora, do jakiej doszło od czasu naszego oksfordzkiego spotkania. W ciągu ponad trzech minionych dekad zdarzyło mi się dwukrotnie podjąć z nim dyskusję. W 1994 roku Legutko opublikował w Critical Review artykuł, w którym ostro skrytykował leżącą u podłoża Berlinowskiego liberalizmu koncepcję pluralizmu 
wartości (Legutko, 1994: 1-22). Poddałam w wątpliwość niektóre aspekty argumentacji krakowskiego filozofa. Po kilkunastu latach w kolejnej pracy Legutko zmodyfikował swoje stanowisko, rezygnując z zakwestionowanego przeze mnie wątku. Po ukazaniu się w 2007 roku jego Traktatu o wolności, w którym przypuścił obcesowy atak na koncepcję liberalną Berlina, poczułam się wręcz zobowiązana do zabrania głosu. W porównaniu do wcześniejszej krytyki, która miała charakter intelektualnej dyskusji, rozwinięta w Traktacie polemika z nieżyjącym już wówczas oksfordzkim filozofem o wiele bardziej przypominała paszkwil niźli racjonalną argumentację. Dość przytoczyć fragment książki, traktujący o Dwóch koncepcjach wolności Berlina. Wedle Legutki słynny esej stanowi „zbiór banatów i fałszów o dużym stopniu szkodliwości dla poważnego myślenia o poważnych problemach" (Legutko, 2007: 6). W obszernej recenzji Traktatu wykazałam nieadekwatność przedstawionej w nim interpretacji poglądów Berlina i wysunęłam liczne argumenty krytyczne przeciwko własnej koncepcji Legutki.

Rozważmy poczyniony niedawno przez krakowskiego filozofa wkład w ogólnopolską dyskusję na temat pedofilii w Kościele, inspirowaną filmem braci Sekielskich Tylko nie mów nikomu. W wypowiedzi europosła Prawa i Sprawiedliwości dla Radia Zet padły następujące słowa (poniższy zapis jest dosłowną transkrypcją wygłoszonego komentarza):

Sprawy nadużyć seksualnych, nazwijmy to elegancko, wśród [...] duchownych, to tak naprawdę przypadki pedofilii są niezwykle rzadkie. To, z czym mamy do czynienia, to mamy do czynienia $z$ homoseksualizmem. Po prostu są badania, jeszcze powtórzone kilkukrotnie, episkopatu amerykańskiego, są też chyba niemieckiego, i wszędzie się powtarza to samo, że ponad 80 procent owych nadużyć dotyczy chłopców w wieku od lat 12 do tam 17 lat. To przepraszam bardzo, co to jest za pedofilia? To nie jest żadna pedofilia, to jest pederastia po prostu. W żargonie nazywa się to mafią lawendową. Jeśli gdzieś jest problem w Kościele, to właśnie tutaj. Film Sekielskiego został wykorzystany w zamiarze uderzenia w prawą stronę, w Kościół (Pietraszewski, 2019b).

Rozważmy stosunki zakresowe między trzema nazwami, które pełnią w tej wypowiedzi kluczową rolę: pedofilia, pederastia i homoseksualizm. Z psychologicznego punktu widzenia pedofilia to stan, w którym głównym lub wyłącznym sposobem osiągania satysfakcji seksualnej jest kontakt z dziećmi w okresie przedpokwitaniowym lub we wczesnej fazie pokwitania. Psychologia wyodrębnia ponadto hebefilię, która dotyczy podstawowego bądź wyłącznego zainteresowania seksualnego dziećmi, które osiągnęły pokwitanie (zazwyczaj między 11 a 14 rokiem życia), oraz efebofilię, która jest analogicznym zaburzeniem preferencji seksualnych, ukierunkowanym na adolescentów w późniejszym okresie dojrzewania (zazwyczaj pomiędzy 15 a 19 rokiem życia) ${ }^{5}$. W wypowiedzi

5 Źródło: typologia podana przez psychologa i psychoterapeutę ks. Jacka Prusaka (Prusak, 2019: 40-41). 
europosła mieszczą się wszystkie trzy typy zaburzeń. Zgodnie z Encyklopedia $P W N$ homoseksualizm

oznacza podejmowanie zachowań seksualnych z osobami tej samej płci, przy istniejącej możliwości swobodnego wyboru partnera erotycznego; o homoseksualizmie rzeczywistym można mówić wtedy, gdy zachowania te są preferowane i mają charakter stały podstawowe znaczenie dla rozpoznania homoseksualizmu ma homoerotyczna motywacja, a nie sam rodzaj praktyk seksualnych, które nie muszą być zgodne z preferencjami seksualnymi (Encyklopedia PWN).

Znaczenie pederastii przybliżył sam europoseł, wyjaśniając, że „termin «pederastia» oznacza w tłumaczeniu z języka greckiego «miłość do chłopców», a szerzej określa zachodzenie związków seksualnych między mężczyznami a dojrzewającymi młodzieńcami” (Tygodnik Solidarność, 2019).

Skoncentrujmy się na kluczowym dla wypowiedzi Legutki pojęciu: „pedofilia”. Wydaje się, że w dyskusji o przestępstwach, jakimi są nadużycia seksualne w Kościele, kardynalnym rozumieniem terminu „pedofilia” jest jego interpretacja prawna. Polski kodeks karny posługuje się tym pojęciem tylko raz, w kontekście penalizacji propagowania lub pochwalania zachowań o charakterze pedofilskim (art. 200b). Kodeks nie zawiera przy tym definicji legalnej tego rodzaju czynów. Niemniej w artykule 200, traktującym o seksualnym wykorzystaniu dziecka i kluczowym dla kwalifikacji prawnej wchodzącego w grę przestępstwa, kodeks posługuje się frazą „małoletni poniżej lat 15”. A zatem zachowania pedofilskie dotyczą właśnie małoletnich.

Jak zatem ma się pedofilia do pederastii? Jeśli mamy na myśli pedofilię w jej psychologicznym znaczeniu, to między zakresami wspomnianych terminów zachodzi stosunek przeciwieństwa. Pedofilia bowiem to zaburzenie dotyczące dzieci przed pokwitaniem, zaś pederastia - chłopców w okresie dojrzewania. Jeśli jednak punktem wyjścia do zbadania relacji jest prawne rozumienie pedofilii, to zakres tego terminu pozostaje z denotacją słowa "pederastia” w stosunku krzyżowania. Bowiem niespełna 15-letni dojrzewający młodzieniec może być zarówno ofiarą pedofilii w jej prawnym znaczeniu, jak i obiektem pederastii. Dla oceny wartości logicznej wypowiedzi Legutki kluczowa jest jednak odpowiedź na pytanie: czy pederastia obejmuje wszystkie przypadki nadużyć seksualnych w Kościele? Z całą pewnością nie, tyczą się one bowiem również dziewczynek, a także chłopców w okresie przedpokwitaniowym. W następnej kolejności rozważmy stosunek między zakresami nazw: „pedofilia” i „homoseksualizm”. Nie ulega wątpliwości, że w grę wchodzi relacja krzyżowania. Są bowiem pedofile, którzy są równocześnie homoseksualistami, i są tacy, którzy są heteroseksualni; są także osoby homoseksualne, które są równocześnie pedofilami, jednak większość z tych pierwszych odczuwa pociąg do dorosłych, a nie do dzieci. Wreszcie, jak się ma pederastia do homoseksualizmu? Odpowiedź nie budzi 
wątpliwości - wszyscy pederaści są homoseksualni, ale tylko niektóre osoby homoseksualne są pederastami. Mamy zatem do czynienia z relacją podrzędności zakresowej. Tym samym wysunięta przez europosła teza, na mocy której nadużycia seksualne w Kościele to nie pedofilia, lecz pederastia bądź nadrzędny względem niej homoseksualizm, jest fałszywa. Z całą bowiem pewnością molestowanie, którego doznała ze strony swego katechety 7-letnia bohaterka filmu Sekielskich Anna Misiewicz nie było przejawem ani pederastii, ani homoseksualizmu. Sprawa przedstawia się tak samo w przypadku 11-letniej ofiary księdza Henryka Jankowskiego, Barbary Borowieckiej.

Dokonana przez Legutkę manipulacja słowna stanowiła pewną innowację w stosunku do omówionych wcześniej zabiegów językowych. Europoseł bowiem nie zbudował definicji perswazyjnej niewygodnego terminu ani nie zmodyfikował jego znaczenia w inny sposób. Co więcej, nie rozszerzył także zakresu pojęcia, którego treść chciał zaciemnić ani też go nie zacieśnił. „Kuglarska sztuczka” (by posłużyć się frazą Berlina) ${ }^{6}$, którą europoseł zastosował, zasadzała się na jawnym, a zarazem arbitralnym zastąpieniu go dwoma innymi pojęciami. Denotacja zarówno pierwszego, jak i drugiego z nich krzyżuje się z zakresem pojęcia wyjściowego. W efekcie rozważana materia uległa zaciemnieniu i zagmatwaniu w stopniu, który skutecznie utrudnia jej zrozumienie. Chciałoby się rzec - znać rękę filozofa.

$\mathrm{Na}$ zakończenie nawiążę do przemyśleń warszawskiego teoretyka prawa, profesora Marcina Matczaka. Snując refleksję nad schorzeniem, na jakie od kilku lat cierpi nasz język, Matczak przywołuje następujące przykłady:

Dla jednych polskość to zamknięcie na świat, dla drugich otwarcie. Dla jednych to przeszłość, dla drugich przyszłość. „Chrześcijanin” to dla części Polaków obrońca wiary, rodem z krucjat, traktujący uchodźców jak najeźdźców. Dla innych chrześcijanin to ktoś utożsamiający się z miłosiernym Samarytaninem i troskliwie pochylający się nad cierpieniem innych, choćby byli mu obcy (Matczak, 2018: 22).

Owo „rozdarcie na pół języka” ma bezpośrednie przełożenie na przepaść, która podzieliła polskie społeczeństwo. Zafałszowywanie treści pojęć nie jest zatem typowym akademickim problemem, który nie wywiera większego wpływu na codzienne życie. Wręcz przeciwnie. Zgodnie bowiem z diagnozą Matczaka:

Nadanie słowom nowych znaczeń powiększyło chaos i podzieliło ludzi w sposób najgorszy z możliwych. Uniemożliwiło komunikację między dwiema stronami sporu. A strony, które nie mogą się porozumieć, na zawsze w tym sporze pozostaną, bo nie mają narzędzia, którym spór ten można załagodzić — nie mają wspólnego języka (Matczak, 2018: 25).

${ }^{6} \mathrm{~W}$ oryginale: sleight of hand. Jak pamiętam, Berlin wielokrotnie używał tego wyrażenia w czasie naszych rozmów na temat wypaczeń pojęcia wolności. 
Był taki czas, kiedy miałam z profesorem Ryszardem Legutką wspólny język. To ten sam okres, w którym ów starszy ode mnie, głębiej wykształcony i finezyjny erudyta był dla mnie autorytetem. Ku mojemu żalowi ten etap już nieodwołalnie przeminąt. Niemniej muszę przyznać, że intelektualna sprawność Legutki nieodmiennie robi na mnie wrażenie. Bowiem podczas gdy wspomniana zapowiedź lidera partii rządzącej, dotycząca zadań nowej konstytucji, w pełni wpisuje się w przemyślenia Stevensona na temat definicji perswazyjnych, manipulacja słowna krakowskiego filozofa konstytuuje nową jakość. Co więcej, zastosowany przezeń manewr o wiele skuteczniej niż technika perswazyjna gmatwa znaczenia terminów i krzyżuje ich zakresy, wprowadzając tym samym językowy zamęt.

Niestety, tego rodzaju zabiegi pociągają za sobą nieuniknione, niszczycielskie następstwo. Zostało ono rozpoznane już przez Konfucjusza. Wyraża je przypisywana chińskiemu myślicielowi maksyma: „Gdy słowa tracą swe znaczenie, ludzie tracą wolność".

\section{BIBLIOGRAFIA}

Berlin, I. (1994a). Dwie koncepcje wolności (s. 178-233). W: I. Berlin. Cztery eseje o wolności. (Przeł. H. Bartoszewicz, D. Grinberg, D. Lachowska, \& A. Tanalska-Dulęba). Warszawa: Wydawnictwo Naukowe PWN.

Berlin, I. (1994b). Wstęp (s. 5-59). W: I. Berlin. Cztery eseje o wolności. (Przeł. H. Bartoszewicz, D. Grinberg, D. Lachowska, \& A. Tanalska-Dulęba). Warszawa: Wydawnictwo Naukowe PWN.

Encyklopedia PWN. Online: https://encyklopedia.pwn.pl/haslo/homoseksualizm;3912545. html (10.06.219).

Hayek, F. (1981). Law, legislation and liberty (Vol. 3: A political order of a free people). Chicago: University of Chicago Press.

Hayek, F. (2003). Droga do zniewolenia. (Przeł. K. Gurba, L. Klyszcz, J. Margański, \& D. Rodziewicz). Kraków: Arcana.

Hayek, F. (2007). Konstytucja wolności. (Przeł. J. Stawiński). Wydawnictwo Naukowe PWN [wyd. 1: 2006].

Huxley, A. (1957). Niewidomy w Ghazie. (Przeł. M. Godlewska). Warszawa: Państwowy Instytut Wydawniczy.

Kołakowski, L. \& Mentzel, Z. (2008). Czas ciekawy, czas niespokojny (cz. 2). Kraków: Wydawnictwo Znak.

Kołakowski, L. (2006). Wolność i wolności (s. 330-339). W: L. Kołakowski, Czy diabeł może być zbawiony i 27 innych kazań. Kraków: Wydawnictwo Znak.

Legutko, R. (1994). On postmodern liberal conservatism. Critical Review, 8, 1-22.

Legutko, R. (2007). Traktat o wolności. Gdańsk: Wydawnictwo słowo/obraz terytoria.

Matczak, M. (2018). Rozdarte języki. Tygodnik Powszechny, 18 listopada, 22-25.

Mrożek, S. (1961). Na petnym morzu. Online: http://polski.gim26.gda.pl/Na\%20pelnym\%20 morzu.htm (10.06.2019).

Musierowicz, M. (2015). Feblik. Łódź: Wydawnictwo Akapit Press.

Orwell, G. (1988). Rok 1984. (Przeł. T. Mirkowicz). Warszawa: Państwowy Instytut Wydawniczy. 
Pietraszewski, M. (2019a). Konwencja PiS: Kaczyński mówi o wolności, Morawiecki zwraca się do... blogerów i youtuberów. Online: https://wiadomosci.radiozet.pl/Polska/Polityka/ Konwencja-PiS.-Przemowienie-Jaroslawa-Kaczynskiego-m.in.-o-wolnosci-w-internecie (10.06.2019).

Pietraszewski, M. (2019b). UJ krytykuje Legutke po stowach nt. pedofilii w Kościele. „Godzi $w$ godność ofiar przestępstw". Online: https://wiadomosci.radiozet.pl/Polska/Polityka/UJkrytykuje-Legutke-po-slowach-nt.-pedofilii-w-Kosciele (10.06.2019).

Polanowska-Sygulska, B. (1998). Filozofia wolności Isaiaba Berlina. Kraków: Wydawnictwo Znak.

Polanowska-Sygulska, B. (2011). Rozmowy z oksfordzkimi filozofami. Kraków: Księgarnia Akademicka.

Polanowska-Sygulska, B. (2012). Między filozofia polityczna a filozofia prawa. Kraków: Księgarnia Akademicka.

Prusak, J. (2019). Drapieżcy w sutannach. Tygodnik Powszechny, 2 czerwca, 40-41.

Rand, A. (2007). Źródto. (Przet. I. Michałowska-Gabrych). Poznań: Wydawnictwo Zysk i S-ka.

Rzeczpospolita (2019). Kaczyński: Przyjdzie taki dzień, że zmienimy konstytucje na potrzebna. Online: https://www.rp.pl/Prawo-i-Sprawiedliwosc/190809823-Kaczynski-Przyjdzie-taki -dzien-ze-zmienimy-konstytucje-na-potrzebna.html (10.06.2019).

Stevenson, Ch.L. (1944). Etbics and language. New Haven: Yale University Press.

Tygodnik Solidarność (2019). Prof. Legutko zapowiada pozwy za minipulacje jego stów nt pedofilii. Online: https://www.tysol.pl/a32502-Prof-Legutko-zapowiada-pozwy-za-manipulacjejego-slow-nt-pedofilii (10.06.2019). 